\title{
LEXICAL AND SYNTACTIC PECULIARITIES OF UKRAINIAN POLITICAL DISCOURSE
}

\section{Dziubak N. M.}

\section{INTRODUCTION}

Political communication has become a popular subject of scientific interest today. The problematics of political linguistics in Ukrainian science is quite large-scale and covers both general theoretical issues and the study of particular aspects of political communication. The foundations of political discourse theory were laid in the 1950s of the XX century by representatives of Cambridge and Oxford schools of philosophy who analysed the linguistic context of the public thought. The theoretical bases for the development of this problematics are laid in the works of T.A. van Dijk ${ }^{1}$, R. Bart ${ }^{2}$.

Political discourse came in the view of linguists in the 70's of the $\mathrm{XX}$ century. The series of scientific reserches has emerged; there the features of political communication were discussed. in details or briefly. that discusses. Subsequently, a new branch of linguistics - political linguistics began to develop. The proponents of this trend studied specific units within political texts (works of: A. M. Baranova, Yu. M. Karaulova ${ }^{3}$, N. Kupina ${ }^{4}$, O. L. Mykhaleva ${ }^{5}$, A.P. Chudinov ${ }^{6}$, O. I. Sheihal ${ }^{7}$ and others). The monographs of L. P. Nahorna ${ }^{8}$, N. Kondratenko ${ }^{9}$ has appeared in the national linguistics.

1 Дейк ван Т.А. Язык. Познание. Коммуникация / пер. с англ. ; сост. В.В. Петрова ; под ред. В.И. Герасимова. Москва, 1989. 312 с.

${ }^{2}$ Барт Р. Миф сегодня. Избранные работы: Семиотика. Поэтика. Москва, 1994. C. $72-130$.

${ }^{3}$ Баранов А. Н., Караулов Ю. Н. Русская политическая метафора : материалы к словарю. Москва, 1991. 193 с.

${ }^{4}$ Купина Н. Тоталитарный язык : словарь и речевые реакции. Екатеринбург Пермь, 1995. 144 с.

5 Михалева О.Л. Политический дискурс : Ссецифика манипулятивного воздействия. Москва, 2009. 216 с.

6 Чудинов А.П. Политическая лингвистика : учеб. пособие. Изд-е 4-е. Москва, 2012. 265 c.

${ }^{7}$ Шейгал, Е.И. Семиотика политического дискурса. Волгоград, 2000. 368 с.

8 Нагорна Л.П. Політична мова і мовна політика: діапазон можливостей політичної лінгвістики. Київ, 2005. 315 с.

${ }^{9}$ Кондратенко Н. Український політичний дискурс. Текстуалізація реальності : монографія. Одеса, 2007. 156 с. 
The relevance of the study of political discourse is caused, first of all, by the specificity of the object of study. There is the necessity of scientific justification for this phenomenon, although there is still no consensus on the understanding of political discourse by representatives of different sciences. In this research we define political discourse as a particular communicative product of political communication, that is defined as political activity itself and as a result. Political discourse is an essential component of the sociocultural interaction between the representatives of the authorities and people. Interests, goals, styles and formation of certain public opinion, that is necessary for the author of the discourse, are the characteristic features of this interaction. The events that are taking place in the Ukrainian political space, where the system of political communication mechanisms and technologies that influence the political reality of Ukraine acts, cannot be ignored or analysed ass it can help to prevent possible attempts at manipulation by the public consciousness during political communication.

\section{The lexical means of Ukrainian political communication}

The most important unit of expression in political communication is the word. And although in communicative linguistics the word is not considered as a unit of communication, it is a means of logical expression of thought, which realises the number of expressive possibilities: it is a means of updating information, performs an evaluative function, has an emotional and expressive meaning. These characteristics of the word in the political branch help to create a message that will help to achieve a specific communicative goal: it will have a decisive influence on the formation of public consciousness etc. The lexical system of modern Ukrainian has wide expressive possibilities. The vocabulary reflects the national character of the language, represents the mental picture of the world, reflects modern trends in the development of the human world, science, technology, which indicates the degree of development of the society, its administrative and territorial structure, level of education and culture, defines material and spiritual values.

The basis of any speech is the common vocabulary. Of course, during the process of the content analysis of political texts we did not take into account all the vocabulary used in the message (text), but only those words that are the key in theb shaping of the message content.

In the discourses analysed, the largest group of common words consists of the names of persons, including:

1) names of persons by nationality: But we all overcome it, because each of us is Ukrainian. We are all Ukrainians, there are no big or small, right or wrong. All are Ukrainians - from Uzhhorod to Luhansk, from Chernihiv to Simferopol, in Lviv, Kharkiv and Donetsk, in the Dnipro and Odesa - we are all Ukrainians (V. Zelenskyi, May 20, 2019). We have to 
become Icelanders in football, Israelis - in defense of our native land, Japanese - in technology, Swiss - in the ability to live happily with each other, despite any differences (V. Zelenskyi, 20.05.2019);

2) names of people by occupation, profession, position: And then it sounded like a childish joke, but then I realised that it was actually true. Because each of us is the President (V.Zelenskyi, May 20, 2019). Remember the Icelandic football team at the European Championships when a dentist, a director, a pilot, a student and a cleaner fought and defended the honor of their country and did so, although no one believed (V.Zelenskyi, 20.05.2019). I have met with the agrarians several times in recent weeks (V.Zelenskyi, 14.04.2016). Yesterday, under the walls of the Ukrainian Parliament, a bloody tragedy was organised, organised by special services, in our opinion, which resulted in the death of innocent Ukrainian servicemen who became the victims of this tragedy (O. Liashko, September 11, 2015). Hundreds of experts, legal scholars, economists, sociologists, constitutionalists, representatives of the Ukrainian creative class, civil society have been working on the New Course of Ukraine for more than four years (Y. Tymoshenko, February 11, 2019);

3) names of persons according to the social grounds: And my election proves: citizens are tired of experienced, systematic, inflated politicians who for 28 years have created a country of opportunities - opportunities of kickbacks, flows, deribans (V. Zelenskyi, 20.05.2019);

4) names of persons according to family relations: After winning the election, my six-year-old son said: "Dad, I saw on TV - they say that Zelenskyi is the President" (V. Zelenskyi, 20.05.2019);

5) names of persons by financial position: We all have to be aware that because of low tariffs the state actually has subsidised everyone - both the poor and the rich, because the same subsidy was hidden in the difference in tariffs (V. Hroisman, 14.04.2019). State support - is not to the oligarch' enterprises, but only to those national producers who have the development plan and are able to produce competitive products (O. Liashko, May 20, 2014);

6) names of persons by place of residence or way of life: Land sale is the millennium scam! I will not allow anyone to sell the land to foreigners, but on the contrary I will change the state policy for the land to feed the Ukrainian peasants (O. Liashko, 18.07.2019);

7) names of party affiliates: Why don't you say a single word of condolence, neither you nor the regionals? (O. Liashko, May 13, 2014). Many, many negatives and lies talk about me, and you think about if at least even one representative of the bandit power or commune came to the city and spoke to you in the absence of security and gave an opportunity to talk about your problems (O. Liashko, 20.05.2014). 
These lexical means are the basis of expression, they do not have a particular stylistic loading, but rather perform an identification function: indirectly mark the addressee of the speech for which a politician is fighting, or identify the objects of political influence against which the politician or society is directed. The modern democratisation of politics determines the priority of human values over the state values, that is why the use of lexemes for denoting persons by family relations determines the fact that the politician, like the average citizen, is, above all, a person with his/her weak and strong traits.

In this aspect, the common names, in particular, the names of the organs of the human body, realise the expressive effect of influencing the addressee of political discourse: Dear people, throughout my life I have tried to do my best to make Ukrainians smile. I have felt it with my heart (V. Zelenskyi, 20.05.2019). We no longer have the right to act on the principle that the right hand does not know what the left is doing, when decisions are being "footballed" for months from ministry to ministry, when tasks are set that no one does and no one is responsible for (V. Hroisman, 04.14.2019). Without economic recovery, we will never be on our own feet (V. Hroisman, 04.14.2016). Only Liashko can do this, and they lie about me because they are scared, because they do not want to be able to lift Ukraine from its knees and do good not only for themselves but also for people (O. Liashko, 20.05.2014). From the above statements it is obvious that the vocabulary of this semantic group in phraseologisms expresses the message, making relevant the most valuable syntagm in the communicative and pragmatic terms.

Certain common names define concepts that are problematic in the public consciousness of the Ukrainians. This semantic group includes nouns common names that mark the item and infrastructure: Somewhere roads and sidewalks are repaired, somewhere - kindergartens and schools, somewhere - clinics and hospitals <...> These are the signs so far because for a year or two all the holes, that have been made for years, it is impossible to cope with (V. Hroisman, 14.04.2016). These are mythical Ukrainian roads that are built and repaired only in someone's stormy imagination (V.Zelenskyi, 20.05.2019). The above lexemes prove that the representative of the government is aware of the people's problems, but they do not say that the official will solve them.

The names of abstract concepts that are perceived as universal values have a special function of influence in political discourse, for example: Not those $73 \%$ who voted for me, but all 100\% of the Ukrainians. This is not my, it is our common victory. And this is our common chance, for which we all are responsible (V.Zelenskyi, 20.05.2019). Yes, those who did not find a home but found work abroad, those who are made to lose their dignity in the fight against poverty (V. Zelenskyi, 20.05.2019). One of the key tasks we all 
are facing today is to restore trust to the authorities (V. Hroisman, 14.04.2019). Such leaders should be replaced by those who know what is love, respect for their neighbor (Yu. Tymoshenko, 12.02.2018).

Despite the positive semantics of the words in bold type, the abstract vocabulary is perceived differently by the recipients and does not have a clear content thatallows its use in manipulative texts, where the meaning is "blurred" and the words indicate what the manipulator needs in a particular text, for example slogans of the notorious Party of Regions: Stability and prosperity! A vote for our party is a vote for stability, prosperity and freedom. We are able to do this if we receive the mandate of your trust (2014).

We also come across some abstract names that are associated with the negative phenomena of socio-political life in society that have arisen because of unsuccessful political decisions, low economic development, etc.: The first thing to do is to realise that the state can and must fight unemployment realistically, should actively, I would rather say, even aggressively, ensure the providing of their citizens with work (V. Hroisman, 14.04.2019). Authoritarianism, aggression, hatred, war - this quality of leadership has no future. Leaders, who profess such archaic remnants of the past, will go into oblivion themselves, along with war, hatred, along with all the bad that they are offering to the world today. I think it will happen soon (Yu. Tymoshenko. 12.02.2018). By means of such lexemes politicians not only criticize the authorities, but also influence the thoughts and emotions of the most vulnerable sections of the population, forcing fear, hysteria; they are trying to cause panic in society, provoking aggressive protests and actions.

V. Cherniavska has studied the suggestiveness of the linguistic means in political communication, among which the main place belongs to lexical ones. In her opinion, there is a number of means - "both lexical, grammatical, and stylistic levels of language, which have powerful influential potential and are able to put some or other related meanings into focus" ${ }^{\prime 10}$. To the lexical means of suggestion the author refers words that have abstract semantics, which is why they are used without concretisation and can denote different meanings. Such lexemes have an emotionally expressive positive color and appeal to ideological values - freedom, justice, honesty, etc. H. A. Kopnina calls them "affective words" that "lose their specific historical, ideological significance and may have different meanings in different political systems" 11 .

The language of political discourse is impossible without proper names. The identity of the unit is a leading feature of its own name. A feature that

10 Чернявская В.Е. Дискурс власти и власть дискурса: проблемы речевого воздействия. Москва, 2006. 136 с.

${ }^{11}$ Копнина Г.А. Речевое манипулирование. Москва, 2008. 176 с. 
distinguishes proper and common names (appellatives) is related to the concept: common names are carriers of concepts, and proper names include all the information known by the speaker about their denotata without some generalisations, and therefore they only relate to the concepts in the way they indicate the type of objects to which their denotata belong.

The most common proper names in political discourse are:

- geographical proper names that represent the geopolitical picture of the world, the political orientation of individual states and groups, namely: 1) the names of parts of the world: Yes, we have chosen the path to Europe. But Europe is not there, it is here. And when Europe is here, it will be here, it will be in Ukraine (V. Zelenskyi, 20.05.2019). The Ukrainians in Europe and Asia, North and South America, Australia and Africa - I appeal to all the Ukrainians on the planet: we really need you (V.Zelenskyi, 20.05.2019); names of states and their associations: You should go to Ukraine not to visit, but to your home, we are waiting for you (V. Zelenskyi, 20.05.2019). Ukraine should get to know what is happening inside Russia. This will help to have an action plan for different scenarios. A key priority of our work is to support government and non-governmental institutions, which will deal with the serious study of the Russian Federation - namely the study of the relationship between the federal center and federation, centrifugal movements, study the nature of the problems that exist in Russia, and how Ukraine should position itself in certain matters... (V. Ohryzko, 08.25.2019). We will continue work on developing relations with the US, Canada, the $\mathbf{G} 7$ countries, and neighboring countries that are already EU and NATO members $<\ldots>$ We will also help to establish close relations with Moldova and Georgia, which are our partners in a number of issues (M. Bardina, 08.28.2019); the names of cities that are world political centers: We have to give a clear signal to our international partners that there are red lines that we will not cross. The most important future visits are to Washington and Berlin (G. Hopko, 28.09.2019);

2) the names of the world political and military organisations: That is why we hear sayings about "civil conflict" and holding the Crimean referendum under the auspices of the UNO (M. Bardina, 28.08.2019). EU and NATO course declarations should be filled with legislative content (G. Hopko, 28.09.2019);

1. the names of internal political institutions and documents regulating the socio-political life of the state: names of state authorities, ministries, departments, state funds: I am dissolving the Verkhovna Rada of the eighth convocation. Glory to Ukraine! (V. Zelenskyi, 20.05.2019). I would like to pay your attention to the change of the system of interaction between the Government and the Parliament (V. Hroisman, 14.04.2016). Most areas of bilateral foreign policy has remained under the responsibility of the MFA and diplomatic missions abroad, but the dynamics of visits of Ukrainian 
officials indicates the active involvement of the Ministry of Defense, Ministry of Justice, Ministry of Infrastructure, PGO etc. (P. Poroshenko, 16.04.2018). I have some warnings as for the uniting the Ministry of Culture with others - because it is a political brand.. In addition, this may be influence on the funding programs of the Ukrainian Cultural Fund, through which important projects receive funding (T. Peresunko, 08.28.2019); names of law enforcement agencies: Government approves priority action plan by 2020, confirming the necessity to approximate national legislation to EU norms; bringing the Armed Forces to the standards of NATO member states; enhancement of international trade and investment attractiveness (P.Poroshenko, 16.04.2019). Priorities include reforming of the Security Service of Ukraine, setting up a parliamentary committee on oversight of special state security forces, and ensuring transparency of procurement for the security sector (G. Hopko, 09.28.2019); names of public positions: And also I ask you to dismiss the head of the Security Service of Ukraine, Prosecutor General of Ukraine, Minister of Defense of Ukraine (V.Zelenskyi, 20.5.2019); names of state documents, laws: Just now not only I have taken the oath, each of us has laid a hand on the Constitution and each of us has sworn allegiance to Ukraine (V. Zelenskyi, 20.05.2019). That is why I ask you very much to pass the law on abolition of parliamentary immunity, the law on criminal liability for illegal enrichment, the long-suffering election code. In its activities the new Government will be guided by the basic strategic documents that set out the main guidelines for our path to European development: the Ukraine 2020 Strategy, the Coalition Agreement, which was prepared and signed in 2014 by all five factions that formed the European Ukraine Coalition., The Association Agreement between Ukraine and the European Union; Strategic documents signed with our international partners, the Legislative Reform Plan, which was approved in this room last year (V. Hroisman, 14.04.2019). We will achieve the organisation of a real negotiation process and the restoration of peace in accordance with the Budapest Memorandum (Yu. Tymoshenko, 11.02.2019);

2. anthroponyms, including the names of heads of states, civil servants, politicians: If he does not rely on a majority, then a new coalition should be formed, then a new leadership of the country should be selected from the government to the Speaker of the Verkhovna Rada, and in fact, I am very impressed by Margaret Thatcher's experience when such situation occured, she said very clearly: no support, let's put to a vote again. And only after getting the quorum trust she made these reforms (Yu. Tymoshenko, 02.11.2019). And the special envoy of the Department of State Kurt Volker was appointed, the US budget for 2018 provided $\$ 350$ million for security assistance to Ukraine and Ukraine authorised providing lethal weapons defense implications (P. Poroshenko, 04.16.2018). 
The defined own names give an idea of the political structure of the state, its power institutions, reveal the concept of state policy, determine foreign policy. In the speech of politicians they have an informative load, as well as indicate the personal connections and rank of the people's deputies in the sphere of politics.

Terms play a special role in political discourse.The scientific term clearly and unambiguously defines a clearly shaped special concept of any branch of science, technology, art, social life, etc., and its relation with other concepts within the special sphere. The level of a politician's ability to use scientific terminology determines the level of his or her intellectual development and education. In the analysed political discourses we have faced the groups of terms which call:

1. concept of financial industry: These are shocking tariffs, humiliating wages and pensions, painful prices, non-existent jobs (V. Zelenskyi, 20.05.2019). From the Government that has been formed today, people are expecting first of all responsible policy, real actions that will bring Ukraine out of the crisis (V. Hroisman, 14.04.2016). I would like to emphasize that maintaining of macro-financial stability and effective cooperation with our international partners is a critical condition for our further development (V. Hroisman, 14.04.2016). Our previous experience, in particular when adopting the budget for this year, shows that, within the framework of the basic parameters that we define together with our international partners, there are different ways to achieve the goals (V. Hroisman, 14.04.2019).These are the debts we have inherited. This is objective reality. Next year, we will spend every third hryvnia on debt servicing (O. Honcharuk, 08.28.2019). I have already mentioned that in Ukraine there can be a mortgage in UAH at 12-13\%. It is absolutely possible to do this next year (O. Honcharuk, 08.28.2019). Millions of the Ukrainians abroad would not take pots out: neither I, as the president, would register offshore, nor oligarchs, no one would register offshore, and would pay taxes here, and those who would not pay, would answer (O. Liashko, 12.05.2016);

2. socio-political realities: We will build a country of other possibilities, where all are equal before the law, where there are fair and transparent rules of the game, one for all. And in order to do this the people who will serve the folk must come to power (V.Zelenskyi, 20.05.2019). So, dear deputies, you yourself have appointed the inauguration on Monday, the working day (V.Zelenskyi, 20.05.2019). I believe that one of the key prerequisites for such a restoration of confidence is effective public administration (V. Hroisman, 14.04.2016). I want to emphasise that in my understanding a responsible state is a state that executes the social contract, that's why the social policy reforming will undoubtedly be one of our key priorities (V. Hroisman , 14.04.2016); 
3. legal concepts: I can promise you that at all stages - from the preparation of bills to their adoption and subsequent implementation - the Government will be in constant dialogue with Mps (V.Hroisman, 14.04.2016). Create a transparent land cadastre that will make land raiding impossible (O. Liashko, 20.05.2014);

4. economic concepts: And this is possible only through deep reforming, which is required by almost all spheres of our lives (V. Hroisman, 14.04.2016). Our aim is to make Ukraine a permanent European state and to lay the foundations for sustainable economic growth (V. Hroisman, 14.04.2016). By creating liberal rules of the game for business, we must make effective use of incentives to grow our economy. We need to find our place in the global economy and ensure the transition from a commodity-oriented economy to a high-value-added economy (V. Hroisman, 14.04.2016).

Terms have a magical effect on the consciousness of the addressees of the broadcast. First, the existence of terms in the text forms a percentage of trust to the politician, because scientific information is objective, does not require verification, and therefore is perceived by faith. Secondly, the terms of one or another branch of the national economy, science, technology in political speech indicate that politicians are oriented in the respective spheres, are aware of the state of affairs, can influence its improvement. However, in actual practice, the politician constantly appeals to social problems, however, in a populist form. We haven't found in the selected speeches any narrow economic or legal term that would testify not only the level of professionalism of a politician, but also his/her professional activity as a statesman.

In some cases, the terminological vocabulary as a result of the figurative use or in the composition of stylistic figures gets bright expressive shade, for example: But a number of issues that cause significant social resonance remain unresolved (V. Hroisman, 14.04.2016). After all, when pensioners receive UAH 1-1.5 thousand and pensions and utilities make up UAH 700 800, I am not talking about the prices in pharmacies, in shops - this means that pensioners are waiting for that payment as a vial of cyanide potassium (O. Liashko, 26.05.2015). The use of medical and musical terms creates a vivid imagery of the above passages .

The democratisation of society and politics has led to the situation that speech of some people's deputies contains jargon, socially lowered vocabulary, in particular: And my election proves: citizens are tired of experienced, systematic, inflated politicians who have made the country of possibilities in 28 years - kickbacks, streams, deribans (V.Zelenskyi, 05.20.2019). Today, there are 200 deputies in the hall instead of 450. This is one more proof of the correctness of the program of the Radical Party as for the necessity to amend the Constitution and reduce the number of deputies of 
the Verkhovna Rada to 200 people. If 450 deputies can't go to the hall, can't work, then I have a question: why do you need, cattle, here and why do people have to pay you a salary? <...> I cannot tolerate such a mess. The one who is not in the parliament today is a dissenter from the front, you left the front, you left the front of the defense of Ukraine (O. Liashko, 21.02.2017). We are often called the cattle. According to the form-rough, by content - correct, but I think that it is not necessary to offend cattle (V. Lytvyn, 22.02.2017).

The questions relating totens ofbillions of hryvnia - are the change to the Tax code, this excise issue relating to the business - it's opaque resolving in a non-transparent way with the work of some groups of various lobbies and transnational corporations, especially with regard to tobaccoand alcohol. And then it is very difficult to defend their position, and the committee will turn actually is such a lobbying "among themselves", which ... because of which the state will actually not receive a huge sum into the State budget and there are, in particular, risks of corruption (O. Yednak, 22.02.2016).

The transition to the language of the "street" serves as the identification of the politician with the people. Limited use vocabulary not only performs an appraisal function (contains a negative appraisal of the actions of the government, the Verkhovna Rada), but also effectively acts on the recipients. Political affectives realise the axiological component of the picture of the native speakers, they are designed to actualise human values, so they are used in agitation texts as suggestive markers that "trigger" the mechanism of value orientations. Due to this, political affect is also widespread in the image and agitational texts to denote the personal traits of politicians.

Therefore, in the structure of political discourse, vocabulary has a number of specific features. Words are used not only as components of the content unit of the content - sentence, but also as a means of actualisation for shaping the expressiveness of the message, but also for the purpose of: influencing the addressee's consciousness, creating a political image, original expression of ratings.

\section{Syntactic means of Political Speech}

The specificity of political discourse structure involves the use of linguistic means that are equal to words, but express their specificity at a syntactic level, that is, in a phrase or sentence. Although the phrase is not a communicative unit, it does constitute a syntagm at which the individual lexemes realise the communicative-pragmatic purpose of the analyzed speech.

Having analysed the political discourses of the presidential campaign, we have drawn attention to the use of a number of simple and complex phrases, which are the markers of the main points of the presidential candidate program, for example: EUROPEAN WAGE. JUSTICE PENSIONS. 
AVAILABLE MEDICINE. FAIRRATES. HIGH-QUALITY AND AVAILABLE EDUCATION. UKRAINIAN CULTURE AND SPIRITUALITY ( Presidential election program for President of Ukraine Yu. Tymoshenko, 2019). "SEVEN WINS FOR UKRAINE" I. Smeshko look like this: Restoration of stability and control of the state, return of Donbas and Crimea, overcoming of corruption, restoration of middle class of Ukrainian society as a basis of statehood of Ukraine, economic reconstruction of Ukraine, reform of state and political system, construction of real democracy in Ukraine (Presidential election program for President of Ukraine I. Smeshko, 2019). These laconic phrases are a kind of slogans - advertising slogans that catch the eye, are well-remembered and express the essence of the intentions of the people's deputies, and the additional function of actualization here performs graphic design.

In the above slogans among the main groups of lexical units that participate in the expression of speech influence of politics have their preferences, Yu. Tymoshenko uses a common vocabulary - adjectives and adjectives, rarely adverbs with axiological semantics, mostly positively colored. Other politicians also use this process, using certain means in statements, texts. As a rule, if they are not defined as political slogans, they are actualised by repeating or applying in the same text derivative singleroot words with appropriate semantics, in particular: Ukraine today needs more than just new faces. It NEEDS NEW IDEAS! (Presidential election program for President of Ukraine V. Zelenskyi, 2019). We Ukrainians want to be free. <...> Live free - thus free to use our own language. $<\ldots>$ The opportunity to travel freely to Europe will give the earliest possible introduction of a visa-free regime with the EU during the first year of my presidency. By the end of my term of office, I expect to reach the necessary political decisions on the part of the EU and to start negotiations on Ukraine's full membership in the European Union in order to live in a "family free, new". <.. > It is difficult for a poor person to be free because the desperate need to exchange freedom for daily bread hangs over him (Presidential election program of President of Ukraine P. Poroshenko, 2014). THE HONEST PRESIDENT - WILL SERVICE PEOPLE! 〈...> Elections give us a chance to bring professionalism, honesty and conscience back into power. $<\ldots>$ An honest president sets the standard - do as Ido. $<\ldots>$ There will be no President of Business, Offshore and Property Abroad - Honest Service to Ukraine and Ukrainians (Pre-election Program for Presidential candidate A. Hrytsenko, 2019).

I. Smeshko emphasizes on the verbal nouns, which are the center of the slogan, that brings together other components that help to realise the valence of the keyword. 
Allocated lexemes have a magical influence on the consciousness of the extraordinary recipient, form a general positive image of the politician whom the society begins to believe in.

The basic unit of expression in the analysed discourse is the sentence. The vast majority of political broadcasting discourses are narrative in nature, so they are based on narrative sentences. Of course, the normativity of their design depends on the author himself, his education, literacy, culture of speech, etc., compare: Dear colleagues, we have registered a number of resolutions on the annulment of decisions of the Verkhovna Rada, includingbills, which provide for the annulment of our decisions concerning budget. According to the Regulations, these resolutions are submitted to the Regulatory Committee, when the Regulatory Committee makes decisions, they must immediately be submitted to the Verkhovna Rada of Ukraine, they must be urgently submitted and without them it is impossible to sign the bills that we adopted on the budget (A. Parubii, 22.12.2016). Then, under the Regulations, I and my colleague, Anna Hopko submitted our proposals and amendments to this bill. But when we came to the committee, it turns out that our amendments were already rejected, because it turns out that it seemed that the working group had worked a few days before and like $\langle. .$.$\rangle and$ when $\langle\ldots>$ I just want the Ukrainian people and the viewers to understand that when the head of the committee goes to the podium and says that everything was done transparently, everything was done in transparent working groups, all positions were agreed, instead it is absolutely untrue, because then the committee is held, a large number of people, you have no opportunity to express or justify wool its position and it is not transparent democratic way (O. Yednak, 22.12.2016). Of course, the above excerpts are much better in lingual form. In our opinion, the people's deputy should speak the state language and be a model of its use. As we can see from the examples, the sentences are finished and cut off, which indicates the level of tension in the Verkhovna Rada.

Motivational constructions occur when organisational moments are discussed or in emotionally saturated speeches by deputies. From the situation of communication the categoricality of such statements depends on and emotional-expressive coloring, for example: Please come into the hall, prepare for registration. Please invite to the Chamber of Deputies. Colleagues, I'll wait a few minutes. Please invite the deputies to the hall. Dear colleagues, I again ask the deputies to enter the hall so that we can go to work (A. Parubii, 22.12.2016). Therefore, of course, I urge all conscious people's deputies to show their position and to cancel the vote for that illegal, wrong anti-people law. Glory to Ukraine! (Yu. Levchenko, 22.12.2016). Friends, you at least read first to criticize! Do you want these people to be imprisoned, not judges and related institutions. So you then tell 
the truth to the people, not lie to the whole state (R. Kniazevych, December 22, 2016).

Occas ionally, in a political party's speech we record interrogative sentences, for example: Dear colleagues, are you ready to register? <...> And "yes" to vote, those who support the cancellation of our decision, in fact, they support. Colleagues, the position is clear, huh? (A. Parubii, 22.12.2016). So, besides, how are you purging the judiciary ifyou vote for a law that supposedly cleanses illegally?... How can you believe all your other words when you talk about good laws, when you lie in plain textabout the Law of Ukraine "On the Regulation of the Verkhovna Rada of Ukraine" and about your law?! (Yu. Levchenko, 22.12.2016)). It is quite obvious that the question constructs are aimed at finding or clarifying unclear information; rhetorical questions are mostly emotional and expressive means.

The popular means of identifying politicians with the people are personal pronouns, used as the subject, for example: There is really only one division: we and they. We are the People of Ukraine. They are "political retirees" who "swing" from the government to the opposition, from party to party, and constantly create themselves a profitable place, hiding behind inviolability $<\ldots>$ We need to win peace for Ukraine. $<\ldots>$ For the equal development of the regions we will stop concentrating the central authorities in Kyiv (Pre-election program of the candidate for President of Ukraine V. Zelensky, 2019). The value of selected pronouns is enhanced by the use of antithesis, which implements the "own - strange" model. As we have noted in the previous paragraph, the emphasis in the expression of the People's Deputy are often nouns, common or proper names, which denote the spiritual or material values of society and its citizens. The expressive effect of these means is greatly enhanced when these lexemes occupy a favorable grammatical position, in particular, the position of the subject, compare: GOD, FREEDOM, FAMILY and UKRAINE are the highest spiritual values of the Ukrainian people; CULTURE, SCIENCE, LAND AND OWN - will feed Ukraine forever; ELECTIVITY, SOCIAL JUSTICE, LEGALITY AND THE ARMY - will always protect the rights of Ukrainians to life, liberty and happiness, and to defend the state's unity and independence (Presidential Election Program of I. Smeshko, 2019). An additional means of updating the above text is to use homogeneous sub-objects with the corresponding semantics, as well as their graphic design.

An interesting promotional step is used in A. Hrytsenko's program, where the antithesis is based on the predicative parts of the non-cosmic sentences, expressed by single-rooted verbs with opposite semantics, for example: There will be no bottom-up conversations - the top of corruption will be cut off from the first. The president will not select another's business - everyone's property will be protected. There will be no discrimination on racial, lingual, religious, gender or other grounds - there will be protection 
of the rights and freedoms of all citizens, regardless of whether they voted for the president or for another candidate. The President will not be hiding behind his integrity - the President's Impeachment Act will be. There will be no "dear friends" - there will be an inevitability of punishment for all, regardless of party affiliation, government or opposition. No president will care about ratings, avoiding the country's decision-making - will be decisive action, regardless of the election. There will be no populism - the president will sign the resource-rich laws. There will be no imposition of a foreign will on Ukraine - the President will only conclude agreements favorable to Ukraine. There will be no "Cherkasy" clan in power and oligarchic quotas there will be appointment to the posts of the best representatives from all regions, personnel policy on the basis of "three P": professionalism, integrity, patriotism (Presidential election program of President of Ukraine A. Hritsenko, 2019) .Popular means of agitation are outward sentences, mostly elliptical, namely: Young people - quality education, employment, space for self-realisation. Young entrepreneurs - state support and a year of preferential taxation. The senior generation is worthy retirement benefits (Presidential Election Program for President of Ukraine V. Zelenskyi, 2019). In the above messages, due to the ellipse, the information is condensed significantly, and therefore the phrase is marked by conciseness and clarity, and only the minor clauses of the sentence marking the new information are verbalised. However, the detailed analysis of the logical structure of these messages indicates clearly defined objects of political activity of the applicant. In the electorate's subconscious, this technique, on the one hand, confirms the well-known thesis of "fewer words, more cases"; on the other it creates a role-playing part of the politician, the electorate and the tasks facing the addressee.

Political discourse is a complex formation that is syntactically implemented by a series of sentences that form a coherent text. Simple sentences are rarely used and with a specific pragmatic purpose (mainly as political slogans). Much more often we find ourselves in simple, complicated sentences, and complex, multi-component sentences are. indisputable leaders

Popular means of simple sentence complication (predicative parts constructed by simple complicated sentence type are:

1. Your own treatment, for example: Dear Colleagues, The time allotted for the break is over. Please come into the hall and prepare for registration. Please invite to the Chamber of Deputies. Colleagues, I will wait a few minutes (A. Parubii, 22.12.2016). Friends, you at least read first to criticise! (R. Kniazevych, 22.12.2016). Colleagues, good afternoon! Bill 5368 has been intended as a global institutional reform of the GFS (A. Zhurzhii, 22.12.2016). You know, Mr. Head, you can say a saying here, you know, the law is like a breather (S. Yevtushok, 22.12.2016). Dear lawyers, read the 
Regulation in Ukraine, the law! (Yu. Levchenko, 22.12.2016). By our own treatment, we mean a word or group of words included in a sentence with which the speaker addresses the addressee. Communication in the communicative practice of politicians performs a number of functions: marking the beginning of a conversation, identifying the addressee of the speech, is a means of attracting attention, an expression of etiquette, a means of irony or sarcasm, a means of expression of subjective evaluation, etc.

2. Insertion constructions: But unfortunately, qualified experts are leaving the ranks of the judiciary and now the judiciary is... (O. Dolzhenkov, 22.12.2016). You know, colleagues, this ruling, which we are currently considering, is, in my opinion, the last obstacle to the continuation of our effective judicial reform (A. Pomazanov, 22.12.2016). Firstly, I would like to respond to the statements of the great lawyers who have just come forward: the chairmen of the Committee on Legal PolicyLegal Policy! - another lawyer sitting there somewhere behind - who said that there was an ad hoc procedure and we did everything right $\langle$... $>$ Where, by the way, it will be possible for all these 5-year-old judges who were in the Verkhovna Rada today, their They did not appoint in any way, now the Supreme Council of Justice will calmly appoint them, because no problems $<\ldots>$ Well, in the end, this law facilitates the mechanism of withdrawal of capital through the transfer pricing system (Yu. Levchenko, 22.12.2016). Ivchenko, please give the microphone (A. Parubii, 12.22.2016). The editorial board of the government, of course, implies that after the first and second reading the deputies will submit their amendments and they will be considered in accordance with the Rules and Regulations (V. Ivchenko, 22.12.2016). These tools perform the function of subjective expression, order thoughts, point to sources of information, are speakers of language etiquette and the like.

3. Separate members of the sentence, in particular those which are identified in modern linguistics as semi-predicative components: And therefore, I ask you to take into account that we have passed a complete qualitative procedure for all budget bills (A. Parubii, 22.12.2016). Having considered the materials, the transcript of the plenary session, the committee noted that the draft Law on Amendments to the Tax Code, registration 5368, was adopted in the second reading, as a whole, 240 people's deputies voted in favor (P. Pynzenyk, 22.12.2016). They rarely occur and perform message compression.

4. Homogeneous members of the sentence, for example: In Ukraine, the rule of law and justice must be upheld. These principles require a transparent and consistent legal framework, accessible, fair, impartial and competitive justice, the inevitability of punishment for a crime, guarantees of respect for fundamental rights of a person, restriction of state interference in private and public life (P. Poroshenko, 24.04.2019). We were 
and remain a nation of peace. But we will always be ready to defend our land and our freedom. And we will always remember, honor and pray for those who protected us during difficult times (A. Sadovyi, 12.04.2019). In political discourse, homogeneous members of the sentence help to convey the expanded meaning, semantically enrich the utterance. The volume of a homogeneous series, its quantitative expression and lexical and grammatical design depends on the level of linguistic competence of the author of the message, as well as communicative and pragmatic factors of the message. For politicians who are adept at eloquence, each of the sentence structures with homogeneous members has a unique personality, serves as a means of updating the content of the message.

The syntactical structure of political discourse depends on its genre. In particular, in the pre-election programs of 2019 presidential candidates, simple complicated sentences prevail. The addressees design the message so that it can be readily and clearly communicated to the addressee, as well as to avoid difficulty in perception.

During the discussion of the reports at the sessions of the Verkhovna Rada, the statements are more broad. The vast majority of sentences are complex, multi-constituent entities that help convey the addressee's thoughts in great detail. We come across complex multicomponent sentences of the following types:

1) complex multicomponent sentences with subordinate and coordination connection: Euromaidan arose when the then authorities at the last moment refused to sign the Association Agreement with the EU, but this was only an excuse (P. Poroshenko, 24.04.2019). Dear Dmitry, the position of our faction is constructive, because it is absolutely logical that the party, the winner in the election, will nominate its candidate for the post of Chairman of the Verkhovna Rada of Ukraine, and our faction will vote for you and support (M. Papiiev, 08.28.2019);

2) complex, multi-component with consistent subordination: And I want to wish the new Verkhovna Rada a constant sense of responsibility, because today there is a majority in this Chamber capable of making new, rapid and necessary changes (V. Hroisman, 28.08.2019). I would like to inform you that inaccordance with Article 115 of the Constitution of Ukraine, the Cabinet of Ministers of Ukraine, which drew up powers before the newly elected Verkhovna Rada of Ukraine, continues to exercise its powers until the newly formed Cabinet of Ministers of Ukraine begins its work (D. Rozumkov, 28.08.2019);

3) complex multicomponent sentences with heterogeneous subordination: I believe that the achievement of new positive qualitative changes of the country, which must be made to the new Ukrainian Parliament, must be accompanied by the protection of those positive changes that have occurred during these five years (A. Parubii, 28.08.2019). 
4) complex multicomponent sentences with consistent subordination and homogeneous subordination with different ways of combining these commitments: Before opening the first sitting of the Verkhovna Rada of Ukraine of the ninth convocation, I wish to wish the newly elected deputies of Ukraine from today the newly elected deputies of Ukraine differences and ambitions, to unite to stop the bloodshed in the Donbass in the shortest possible time, to return territories and people to Ukraine, to start the revival of the economy of our country (Yu. Ioffe, 28.08.2019). I wish the success of the new composition of the Cabinet of Ministers so that you can do everything in order to openly look people in the eyes and make Ukraine successful (V. Hroisman, 28.08.2019).

In some cases, multicomponent sentences are so widely spread that in speech they are broken down into a series of parceled sentences that are formally distinct but united by semantics, for example: Today I am making a statement from this rostrum on the assignment of these powers. But I would also like to say about three extremely difficult years of our collaboration. Work that was aimed at making sure that every Ukrainian community, in every family, would eventually make people feel that change was happening. But I also understand that much has not been done (V. Hroisman, 08.28.2019).

In political discourse such sentences reflect the close links between the phenomena and processes of social and political life of society, since each predicative part is distinguished by a logically designed message. As a part of a multicomponent sentence, these messages interact with each other, reflecting a hierarchy of phenomena and concepts, features of their subordination, reflecting causal relationships, order of flow, and so on. The location of the predictive parts depends on the relevant information being updated.

\section{CONCLUSIONS}

Political discourse - a set of all speech acts in the socio-political life of a country, which are governed by the laws and rules of public policy, which are defined by tradition and tested by public practice.

In the structure of political discourse vocabulary has a number of specific features. Words are used not only as components of the content unit of the content-sentence, butalso as a means of updating and framing the message, as well as for the purpose of: persuasion, latent influence on the addressee's consciousness, political image, original expression of evaluations, etc. According to the research, the most popular words in political discourse are the words-names of persons by nationality, occupation, position, social characteristics, family relations, financial status, place and way of living, party affiliation. A significant effect of influencing the consciousness of the addre ssee of political discourse is realised by the common names, in particular, the names 
of the organs of the human body that function within the phraseology. The terms add the persuasiveness and the objectivity to political speech .

Political discourse is characterised by a variety of syntactic formulations that depend on the genre of speech. Typical syntactic units are phrases political slogans, simple complicated sentences, and multi-component sentences. The discourses we have analysed testify to the considerable democratisation of the language of politicians, which is approaching in terms of linguistic design to the spoken language. Deputies speak the language of "the street", i.e they do not always adhere to the norms of literary language, culture of speech, etc. There are very few modern deputies who possess the technique of public broadcasting and use some rhetorical techniques. In our opinion, in communication the deputy must not only adhere to the deputy's ethics, but also serve as a model for the use of the state language. It is not surprising, therefore, that the question of the status of the state language is increasingly being raised.

\section{SUMMARY}

The article deals with the peculiarities of the use of linguistic means in the Ukrainian political discourse. Particular attention is given to the lexical and syntactic means that form the basis of the message. The semantic groups of the most commonly used words that form the basis of political communication are identified. The communicative and pragmatic purpose of using proper and common names, as well as terminological vocabulary, which have the function of manipulative influence on the addressees of political broadcasting have been clarified. The peculiarities of the language syntax of politicians are studied. The basic structural and semantic types of syntactic units are considered, and the functions they perform in the political discourse are analysed.

\section{REFERENCES}

1. Баранов А.Н., Караулов Ю.Н. Русская политическая метафора : материалы к словарю. Москва, 1991. 193 с.

2. Барт Р. Миф сегодня. Избранные работы: Семиотика. Поэтика. Москва, 1994. С. 72-130.

3. Дейк ван Т.А. Язык. Познание. Коммуникация / пер. с англ. ; сост. В.В. Петрова ; под ред. В.И. Герасимова. Москва, 1989. 312 с.

4. Кондратенко Н. Український політичний дискурс. Текстуалізація реальності : монографія. Одеса, 2007. 156 с.

5. Копнина Г.А. Речевое манипулирование. Москва, 2008. 176 с.

6. Купина Н. Тоталитарный язык: словарь и речевые реакции. Екатеринбург - Пермь, 1995. 144 с.

7. Михалева О.Л. Политический дискурс : Специфика манипулятивного воздействия. Москва, 2009. 216 с. 
8. Нагорна Л.П. Політична мова i мовна політика: діапазон можливостей політичної лінгвістики. Київ, 2005. 315 с.

9. Чернявская В.Е. Дискурс власти и власть дискурса: проблемы речевого воздействия. Москва, 2006. 136 с.

10. Чудинов А.П. Политическая лингвистика : учеб. пособие. Изд-е 4-е. Москва, 2012. 265 с.

11.. Шейгал, Е.И. Семиотика политического дискурса. Волгоград, 2000. 368 c.

Information about the author: Dziubak N. M.,

Candidate of Philological Sciences, Associate Profess or of Ukrainian Language Department Kamianets-Podilskyi Ivan Ohiienko National University 61, Ivan Ohiienko Str., Kamianets-Podilskyi, Khmelnytsky region, 32301, Ukraine 